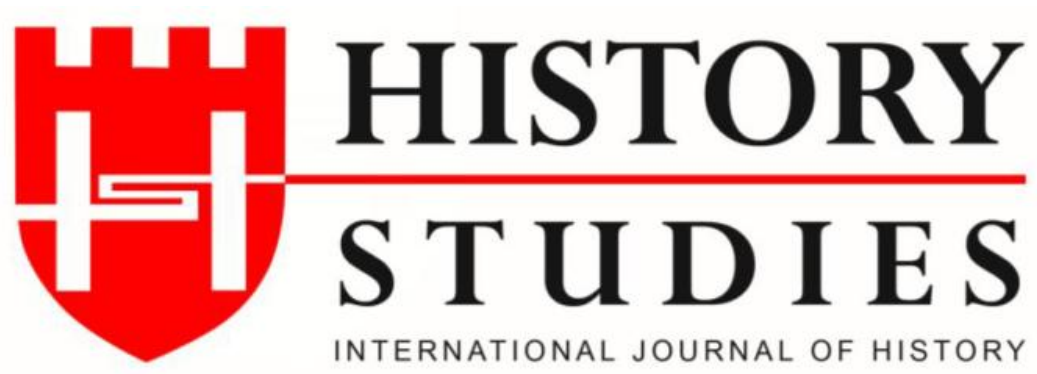

ISSN: 13094173 (Online) 1309 - 4688 (Print)

Volume 12 Issue 6, December 2020

DOI Number: 10.9737/hist.2020.950

Araştırma Makalesi

Makalenin Geliş Tarihi: 11.11.2020 Kabul Tarihi: 24.11.2020

Atıf Künyesi: Miraç Tosun, “Üçüncüzade Ömer Paşa'nın Kariyeri ve Ölümüne Ait Kayıtlar Hakkında

Bazı Gözlemler", History Studies, 12/6, Aralık 2020, s. 2969-2986.

\title{
Üçüncüzade Ömer Paşa'nın Kariyeri ve Ölümüne Ait Kayıtlar Hakkında Bazı Gözlemler
}

\author{
Some Observations about the Career of Ucuncuzade Omer Pasha and the Records of \\ His Death
}

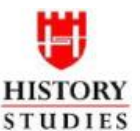

STUDIES

Volume 12

Issue 6

December 2020

\author{
Dr. Miraç Tosun \\ ORCID No: 0000-0002-8587-9557 \\ Karadeniz Teknik Üniversitesi
}

\begin{abstract}
$\ddot{O} z$
\end{abstract}
18. yüzyılda özellikle merkez kaç eğilimler ve bunun ayanlık ile tezahürü bir önceki yüzyıldan imparatorluğu farklılaştıran en önemli karakteristik özelliklerden biridir. Bu yüzyılda Osmanlı taşrasının önemli eyalet merkezlerinden biri olan Trabzon da imparatorluğun içinden geçtiğ dönemin bir aynasıdır denilebilir. Bu yüzyılda kalesi üç defa "eşkıya" gruplarınca kuşatılan, özellikle doğu seferlerinde bir askerî nakliyat merkezi olmasının getirdiği karışıklıklar ile birlikte yukarıda ifade edilen adem-i merkeziyetçi eğilimlerin sık görüldüğü bölgelerden biri olan Trabzon'da devletin güvenlik, asayiş ve merkezi otoriteyi tesis etmesini güçleştirmiştir. Bu yüzyılda gerek doğu gerekse kuzey seferlerinde Trabzon'un oynadığı rol ve Trabzon'a atanan valilerin aynı zamanda bu seferlerde çeşitli zamanlarda serdar olarak tay ini dolayısıyla yönetici açısından başıboş hali bölgeyi özellikle idari açıdan etkileyen en önemli meselelerdendir.

İşte bu meseleler tahtında şehirde görev yapan valiler arasinda Trabzon'daki görevinden hemen sonra Van Valisi iken idam edilmesiyle dikkatleri üzerine çeken en önemli isim Üçüncüzade Ömer Paşa'dır. Ömer Paşa gerek valilik dönemi gerekse bu dönemde ortaya koyduğu mimari eserler ile şehrin tarihine damga vurmuştur denilebilir. Bugün Ganita mevkiinde yaptırmış olduğu Güzelsaray Trabzon'da vazifeleri dolayısıyla bulunan Osmanlı paşaları arasında onu çok ayrı bir yere koymamızı sağlamaktadır. Bunun yanı sıra idamının akabinde Ömer Paşa'nın devlete olan borçları ve mirası Osmanlı bürokrasisini oldukça uğraştırmışa benzemektedir. Bu meseleyle ilgili olarak bu çalışmada özellikle Trabzon Şeriye Sicilleri, Maliye Ahkâm Defterleri ve Topkapı Sarayı Arşivindeki müteferrik defterlerin verilerin ş̧ığında konunun çeşitli veçheleri üzerinde durulmaya çalışılacaktır.

Anahtar Kelimeler: Karadeniz, Trabzon, Ömer Paşa, 18. yüzyıl

\section{Abstract}

The province of the Ottoman Empire in 18th century points to a very troubled period, just as it did a century ago. Especially the emergence of centrifugal tendencies and their manifestation as ayanlık in this century are one of the most important characteristic features that differentiates the Empire from the previous century. Trabzon, one of the important provincial centers of the Ottoman 
provinces in this century, acts as a mirror of the period that the Empire went through. In this century, with its castle besieged by "bandit" groups three times and the confusion especially brought about by its being the military transportation center during the east expeditions, as well as the abovementioned decentralist tendencies, Trabzon is one of the regions where the empire's establishment of security, public order and central authority has strengthened. The most important issues affecting Trabzon in this century are as follows: Trabzon's role in both the eastern and the northern expeditions, the appointment of Trabzon's governors as serdar at various times during these expeditions and the city being left astray in terms of rulers.

In the light of these issues, Ucuncuzade Omer Pasha is the most important name who differs from the governors of Trabzon in that he was executed as the governor of Van right after his duty in Trabzon. It can be said that Omer Pasha marked the history of the city with his architectural works, both during his governorship and during that period. Güzelsaray, which he built from Ganita today, allows us to distinguish him from the Ottoman Pashas who served in Trabzon. After the execution of Omer Pasha, his debts to the state and his legacy seem to have brought the Ottoman bureaucracy to a great deal of trouble. In the light of the data contained in the Trabzon Court Records, the financial orders registers and the müteferrik books in the Topkap1 Palace Archives, we will try to focus on various aspects of this issue.

Keywords: Black Sea, Trabzon, Ömer Pasha, $18^{\text {th }}$ Century

\section{Giriş}

Osmanlı tarihi araştırmalarında devlet ricali biyografileri oldukça önemli bir alanı oluşturmaktadır. Feridun Emecen'in bahsettiği üzere “Tarihi şahsiyetlerin biyografileri, kolay gibi görünen ama aslında zorluklarla dolu bir araştırma sahası olarak dikkati çekmektedir. Tarihi olaylar üzerinde etkili olmuş veya eserler ortaya koymuş, hatta bir bakıma tarihe yön vermiş şahısların hayat hikâyelerinin laylkıyla bilinmesi, hiç şüphesiz tarihin geniş bir perspektif çerçevesinde daha iyi anlaşılmasına imkan verecektir." Emecen bu imkânın mümkün olduğunca resmî kaynakların "kuru" ifadelerinde aranılabileceğini ifade eder. Bir Osmanlı ricalinin hayat hikâyesinin ilk aşamasını elbette onun resmî hayatının resmî kaynaklara göre ortaya konması keyfiyeti oluşturur. Bu çalışmada 18. yüzyılda Trabzon valiliğinde bulunmuş ve akabinde şehre fizikî anlamda damga vurmuş bir mimari yapının da sahibi olan Ömer Paşa'nın kariyer basamaklarında yükselişi, idamına giden sürecin ortaya çıkışı ve idam edildikten sonra vuku bulan meselelere el verdiğince kaynakların yol göstericiliğinde işaret edilmeye çalışılacaktır.

Osmanlı idare tarihi araştırmalarında beylerbeyiler ve yönettikleri eyaletin durumu hakkında önemli araştırmalar ortaya konulmuştur. Bu çalışmaların öncü isimlerinden biri Metin Kunt'tur. Onun Bir Osmanl Valisinin Ylllı Gelir-Gideri Diyarbekir $1670-1671^{2}$ ve Sancaktan Eyalete, 1550-1650 Arasında Osmanlı Ümerası ve Il İdaresi $i^{3}$ isimli kitapları ile "Müteşebbis Bir Osmanlı

\footnotetext{
${ }^{1}$ Feridun M. Emecen, "İki Osmanlı Ricalinin Resmi Hayatlarının Kaynaklarına Dair”, Osmanlı Araştırmaları, Sayı 17, İstanbul 1997, s.91-97. Osmanlı biyografi çalışmalarının yöntem ve kaynak sorunları için bkz. Feridun M. Emecen, "Osmanlı Kronikleri ve Biyografi”, İslam Araştırmaları Dergisi, Sayı: 3, İstanbul 1999, s.83-90; Ali Akyıldız, "İnsanı Yazmak:19. Yüzyıl Osmanlı Biyografi Yazıcıllğı ve Problemleri Üzerine Bir Değerlendirme", Osmanlı Araştırmalarl, Sayı 50, İstanbul 2017, s.219-242; Otur Baştan Yaz Beni: Oto/Biyografiye Taze Bakışlar, yay. haz. Abdulhamit Kırmızı, Küre Yayınları, İstanbul 2013.

${ }^{2}$ Metin Kunt, Bir Osmanlı Valisinin Ylllık Gelir-Gideri Diyarbekir 1670-1671, Boğaziçi Üniversitesi Yay inları, İstanbul 1981.

3 Metin Kunt, Sancaktan Eyalete, 1550-1650 Arasında Osmanlı Ümerası ve Il İdaresi, Boğaziçi Üniversitesi Yayınları, İstanbul 1978.
} 
Veziri: Derviş Mehmed Paşa"4, isimli makaleleri konuyla ilgili erken tarihli en önemli araştırmalardır. Klasik Dönem Osmanlı tarihi araştırmalarında ise paşa biyografilerinden ziyade belirli bir y1lın eyalet yöneticileri veya belirli bir eyaletin ${ }^{5}$ yöneticilerinin tespiti araştırmaları ön plana çıkmaktadır. Bu konuda da Orhan Kılıç'ın çalışmaları zikre değerdir6 . Alpay Bizbirlik'in 18. yüzyıl ortasında içinde Trabzon'un da olduğu imparatorluğun çeşitli vilayetlerinde görev yapan Çelik Mehmed Paşa'nın ölümü sonrasındaki belgelerden hareketle yazmış olduğu makale de alana katkı yapan nitelikteki çalışmalardandır. ${ }^{7}$

Trabzon eyaletinin valilerinin listelerine dair Tahvil ve Nişan Defterleri kaynak olarak kullanılmak suretiyle Mehmet İnbaşs ${ }^{8}$ ve Orhan Kılıç ${ }^{9}$ çalışmalar yapmışlardır. Bunlarla birlikte Trabzon özelinde eyalette beylerbeyilik yapan paşalar hakkında incelemeler mevcuttur ancak incelemelerin yeterli sayıda olduğunu söylemek güçtür. ${ }^{10}$ Kenan İnan'ın “Trabzon'da Yönetici Yönetilen İlişkileri" "l adlı makalesinde konu 17.yy ilk yarısı itibarıyla ele alınmış ve daha çok yönetilenlerle olan münasebetler üzerinden beylerbeyiler değerlendirilmiştir. Ayrıca Mehmet Beşirli’nin “Trabzon Valisi Hazinedarzâde Osman Paşa ve Zamanı (1827-1842)" "12 başlıklı çalışmasının yanı sıra Yunus Özger'in ${ }^{13}$ ve Temel Öztürk'ün ${ }^{14}$ paşa muhallefatlarını inceleyen

${ }^{4}$ Metin Kunt, "Müteşebbis Bir Osmanlı Veziri: Derviş Mehmed Paşa”, Toplum ve Bilim, Sayı: 2, İstanbul 1977, s.43-64.

5 İbrahim Yılmazçelik, "Osmanlı Hâkimiyeti Süresince Diyarbakır Eyaleti Valileri (1516-1838)", Fırat Üniversitesi Sosyal Bilimler Dergisi, Cilt 10, Elazı̆̆, 2000, s.233-287; Nilüfer Bayatlı, "Osmanlı Döneminde Bağdad Valileri(1534-1917)”, Türk Dünyası Araştırmaları, Sayı 158, İstanbul 2005, s.189202.

6 “18. Yüzyıl Osmanlı Eyalet ve Sancak Tevcihatının Sistematik Tetkiki”, XV. Türk Tarih Kongresi:

Volume 12 Issue 6

December 2020

Ankara 11-15 Eylül 2006 Kongreye Sunulan Bildiriler, Cilt IV - I Kısım, s.1025-1044; “18. Yüzyılda Rumili Eyaleti'ne Yapılan Vali Atamalarının Sistematik Olarak İncelenmesi”, Archivum Ottomanicum [ 21 st Symposium of the Comite International des Etudes Pre-Ottomanes et Ottomanes ( Ciepo = CIEPO), 7-11 October, Budapest], Sayı 33. say1, 2016, s.213-234; "Batı Karadeniz Kıyısında Bir Osmanlı Eyaleti: Özi/Silistre (İdari Taksimat ve Yönetim)”,Karadeniz Incelemeleri Dergisi, Sayı 23, Trabzon, 2017. s. 2982.

7 “XVIII. Yüzyılda Bir Osmanlı Valisinin Ölümü Ardından Gelișen Olaylar Üzerine”, Tarih İncelemeleri Dergisi, Say1 15, İzmir 2000, s. 171-181. Ayrıca bkz. Murat Alanoğlu, "XVIII. Yüzyılda Maktul Bir Osmanlı Veziri: Bağdad Valisi Hafız Mustafa Paşa (Ispanakçızade) ve Katli Meselesi”, CIEPO 22: Uluslar arası Osmanlı Öncesi ve Sonrası Çalışmaları Komitesi, 4-8 Ekim 2016 Bildiriler Kitabı, ed.K.İnanM.Tosun-D.Çolak, Cilt 2, Trabzon 2018, s. 527-543.

8 “Trabzon/Batum Eyâleti Valileri (1755-1795)”, A. Ü. Türkiyat Araştırmaları Enstitüsü Dergisi, Sayı 31, Erzurum 2006, s.161-191.

9 “XVIII. Yüzyılın İlk Yarısında Trabzon Eyaletinin İdari Taksimatı ve Tevcihatı", Trabzon Tarihi İlmi Toplantisl (6-8 Kasım 1998), Trabzon 1999, s.179-192.

${ }^{10}$ M. Kemal Yanbeğ'in “17. ve 18. Asırda Azak Kalesi ve Trabzon Valileri” İnan, Sayı 5, Trabzon 1943, s.7-13 çalışması konu hakkında ilk öncü çalışmadır.

${ }^{11}$ Osmanlı Araştırmalart-Journal of Ottoman Studies, Say1 23, İstanbul 2003, s. 22-60.

${ }^{12}$ Karadeniz Tarihi Sempozyumu I, (25-26 Mayıs 2005), Trabzon 2007, s.397-416.

13 “Trabzon Valisi Hazinedarzade Süleyman Paşa'nın Muhallefatı”, Karadeniz Incelemeleri Dergisi, Sayı 2, Trabzon 2007, s. 93-122.

14 “Trabzon Valisi Vezir Abdurrahman Paşa'nın Muhallefatı (1728-1730)”, Türk Kültürü Incelemeleri Dergisi, Sayı 18, İstanbul 2008, s. 9-50; “Trabzon Valisi Üçüncüoğlu Ömer Paşa'nın (1739-1742) Kitap Kültürü”, Osmanlı Sosyal ve Ekonomik Tarihi: Prof. Dr. Yllmaz Kurt Armağanı, II. cilt, Ankara 2016, s. 212-235; “Trabzon Valisi Vezir Abdurrahman Paşa’nın (1728-1730) Kitap Kültürü”, XVII. Türk Tarih Kongresi, Ankara: 15-17 Eylül 2014: Kongreye Sunulan Bildiriler, IV. Cilt III. Kısım, Ankara 2018, s. 1093-1110. 
çalışmaları mevcuttur. Bu yazıda ele alınacak olan Ömer Paşa hakkında ise iki inceleme bulunmaktadır. Bunlar, Necmettin Aygün'ün “XVIII. Yüzyılda Bir Osmanlı Valisi: Üçüncüoğlu Ömer Paşa ve Muhallefatı"15 ile Temel Öztürk'ün "Arşiv Belgelerine Göre Trabzon'da Üçüncüoğlu Sarayı"16 isimli çalışmalarıdır.

$\mathrm{Bu}$ kısa literatür değerlendirmesinden sonra öncelikle 18. yüzyılda Kuzeydoğu Anadolu'da önemli bir eyalet merkezi olan Trabzon'da valilik makamında iki yıl oturan Üçüncüzade Ömer Paşa'nın kariyer basamaklarını tespit etmek ile dönemin ricalinin ne şekilde yükseldiğinin açıklanmasına küçük de olsa bir katkı sağlayacağı düşünülmektedir. Ancak bunun için Paşa'nın hayat hikâyesi ve bulunduğu görevlere dair doğrudan bir bilgiye sahip olduğumuz söylenemez. Zira dönemin kronikleri bu konuda garip bir sessizlik içindedir. Paşa'nın dönemin kitabi kaynaklarında ve vakanüvis tarihlerinde izi bulunmamaktadır. Dönemin kronikleri olan Sami, Şakir ve Subhi tarihleri ${ }^{17}$ ile Fındıklılı Süleyman'ın Müri't- Tevarih'inde ${ }^{18}$ Ömer Paşa'nın Trabzon'a atama kayıtlarının yanı sıra ölümü ile de ilgili bilgi bulunmaz. Bunların dışında Sicilli Osmani' $\mathrm{de}^{19}$ de Ömer Paşa'ya yer verilmez.

Bütün bu eksikliklere rağmen Ömer Paşa'nın kariyer basamaklarını izlemede arşiv belgeleri çeşitli imkânlar sağlar. Bunlar içerisinde özellikle Trabzon Kadı Sicilleri'nin, Mühimme Defterleri'nin, Topkapı Sarayı arşivindeki müteferrik defterler ile Osmanlı arşivinde çeşitli tasniflerde yer alan defterler ve belgelerin ayrı bir yeri vardır.

18. yüzyılda Osmanlı taşrasında ayan ailelerinin ve yerel idarecilerin ortaya çıkışında başat rol devlet adına vergi toplama işinin ihalelerle kazanılmasında aranmaktadır. Bu suretle yerel güç odakları ile merkezden gönderilen paşaların atanmasında bu kriter önemli bir rol oynar gözükür. Adeta devlete ait gelirler belirli şartlar dâhilinde yereldeki güç sahiplerine devredilmektedir. Nitekim Ariel Salzmann bunu İmparatorluğu Özelleştirmek şeklinde tarif eder. ${ }^{20}$ İște Ömer Paşa'yı Osmanlı belgelerinde görünür kılan ilk umdeler de onun bu tür faaliyetlerine aittir.

Belgelerden hareketle yapılan çalışmalarda Ömer Paşa'nın ne zaman doğduğu kestirilememekle birlikte Torul'un Manastır köyünde doğduğu ve babasının da el-Hac Mustafa Efendi olduğu ifade edilmektedir. ${ }^{21}$ Her ne kadar Üçüncüzade hakkındaki arşive dayalı ilk veri 1737 yılında Canik Sancağı muhassıllığını malikane olarak işleten üç kişiden biri olduğu şeklindeyse de adına ilk defa 18 Mart 1736 tarihli Trabzon Beylerbeyisi ve Kefe Seraskeri Mehmed Paşa'nın bir buyruldusunda rastlıyoruz. Buyrulduda Üçüncüzade Ömer, Ağa unvanıyla ve Görele Voyvodası olarak geçmektedir. Bu, onun bizim karşılaştı̆̆ımız ilk resmî unvanıdır. ${ }^{22}$ Kendisinden istenen, bu unvan ile Görele'ye tabi dört köyün buraya bağlı iken Trabzon/Yoros kazası ahalisinin, onları kendi vergi ödemelerine katmak istemelerine engel olmasıdır ${ }^{23}$. Bundan üç ay sonra Sultan I. Mahmud'un 10 Safer 1149/20 Haziran 1736 tarihindeki fermanında

\footnotetext{
${ }^{15}$ Karadeniz Incelemeleri Dergisi, Say1 7, Trabzon 2009, s. 39-77.

${ }^{16}$ Trabzon Kent Mirasi: Yer-Yapl-Hafiza, İstanbul 2010, s. 237-264.

${ }^{17}$ Subhi Tarihi: Sami ve Şakir Tarihleri ile Birlikte 1730-1744 (inceleme ve karşılaştırma metin), Haz. Mesut Aydiner, İstanbul 2007.

${ }^{18}$ Şemdanizade Fındıklılı Süleyman Efendi Tarihi-Müri't-Tevarih, haz. M. Münir Aktepe, 3 Cilt, İstanbul 1976-1981.

${ }^{19}$ Mehmed Süreyya, Sicill-i Osmani, yay. haz. Nuri Akbayar, İstanbul 1996.

20 “İmparatorluğu Özelleştirmek: Osmanlı XVIII. Yüzyılında Paşalar ve Ayanlar”, Osmanlı-İktisat, Cilt 3, Ankara 1999, s.227-235. Aynı Yazar, Osmanlı Ancien Regimei, İstanbul 2011.

${ }^{21}$ Aygün, a.g.m., s. 44.

${ }^{22}$ Voyvodalığın Osmanlı taşra idaresindeki yeri ve gelişim süreci için bkz. Erol Özvar, "Voyvoda", DİA, Cilt 43, İstanbul 2019, s.129-131.

${ }^{23}$ T.Ş.S., nr. 1901, vr. 67b, (5 Zilkade 1148-18 Mart 1736).
} 
Üçüncüoğlu Ömer herhangi bir unvan ibaresi olmaksızın sadece ismiyle zikredilmektedir. Fermanın muhtevasından Üçüncüoğlu'nun Tersane-i Amire'deki kalyonlar için ısmarlanan fakat henüz gönderilmeyen kendir tellerinin bir an önce temini ve Tersane-i Amire'ye teslimi hususunda mübaşirlik vazifesinin olduğunu öğreniyoruz. ${ }^{24}$ Fermanın mübaşirlik açısından bir diğer muhatabı Fatsalı Hacı Ahmed'dir. ${ }^{25}$

Eylül 1736'da yine Görele voyvodası olarak Ömer Ağa, merkezin muhatabı olmuştu; Trabzon valilerine tahsis edilen imdad-1 seferiyenin Görele reayası üzerine düşen payı, buradaki halk Gümüşhane'ye bağlı bulunduklarını iddia ederek, Trabzon'daki vergi yükümlüleriyle ödemekten imtina etmekteydi. Bu durumun engellenmesi İstanbul'un isteğiydi. ${ }^{26}$ Ertesi sene Nisan 1737'deki sicil kaydında Üçüncüzade Ömer, "Trabzon ayanından" şeklinde adlandırılmıştır. "Kar-güzar ve müstakim olması hasebiyle" yine Trabzon imdad-1 seferiyesinin toplanmasinda görevlendirilmiştir. ${ }^{27}$ Yaklaş1k dört ay sonra Ağustos 1737'de Trabzon siciline eklenmiş Darüssaade Ağası Hacı Beşir Ağa'nın mektubunda bu kez Haremeyn-i Şerifeyn evkafına bağlı olan İmaret-i Hatuniye vakfı reayasının mütevellisine ödeme yapmaması üzerine vakıf malının toplanması için mütevelliye yardım etmesi istenmekteydi. ${ }^{28}$ Bundan takriben beş yıl sonra ise Hatuniye vakfı reayasının şikâyetleri, Üçüncüoğlu Ömer'in sonunu hazırlayan etkenlerin başında gelecekti.

Tekrar 1737 yılı sonbaharına döndüğümüzde Trabzon sicilindeki kayıtlarda Üçüncüzade Ömer'in adının Trabzon imdad-ı seferiyesinin toplanmasıyla ilgili olarak geçmeye devam ettiği görülmektedir ${ }^{29}$. $\mathrm{O}$, bu tür vergilerin toplanmasının yanı sıra bölge halkından bazı kimseler ile de yakın ilişkiler kurmuş gibidir. Aynı tarihte Trabzon'da sakin askerî kesimden beş kişinin hapisten kurtulmaları için "hüsn-i hallerini" haber veren ve şuhudulhal kısmında yer alanların ilk sırasında Üçüncüzade Ömer Ağa yer almaktadır. ${ }^{30}$

Volume 12

Bu yılın aynı dönemindeki Mühimme Defteri kayıtlarında Üçüncüzade Ömer'i çok başka bir görev skalas1 ve manzumesi beklemektedir. O, Eylül 1737'de bir mühimme hükmünde "Canik Sancă̆ında Cebeci Zabiti Üçüncüzade Ömer" olarak askeri bir unvanla ve imparatorluğu doğrudan ve daha çok ilgilendiren konularda karşımıza çıkmaktadır. Bu hükümde kendisinden bu yıllarda ortaya çıkan Osmanl1-Rus savaşının Kırım cephesi için bölgesinden asker toplanmasında ortaya çıkan aksaklıkların giderilmesi istenmiştir. Kayıtta "husûs-ı mezbûrun vücûda getürülmesi içün ancak senden matlûb olmağla, Canik Sancağı'nda küşâde olunup elyevm kazâlarında hâzır ve âmâde ve hılâf-ı emr-i âlî te'hîr üzre olan on üç aded serdengecdi bayraklarını ve ağalarını ve tekmîli üzre neferâtlarını bulundukları kazâlarından bir gün evvel alâ eyyi-hâl ihrâc ve me'mûr oldukları Kırım cânibi seraskeri vezîr-i müşârun-ileyhin

\footnotetext{
${ }^{24}$ BOA, AE.SMHD.I, nr.160-12050.

${ }^{25} \mathrm{Bu}$ ismin 18. yüzyılın özellikle ikinci yarısında Karadeniz Tarihine damga vuran Caniklizadelerin atası olduğu bilgisi önemlidir, bkz. Özcan Mert, "Canikli Ali Paşa Ailesi”, DİA, Cilt 7, İstanbul 1993, s.151154; ve ayrica bkz. Canay Şahin, The Rise and Fall of an Ayan Family in $18^{\text {th }}$ Century Anatolia: The Caniklizade's(1737-1808), (Bilkent Üniversitesi Ekonomi ve Sosyal Bilimler Enstitüsü Yayımlanmamış Doktora Tezi), Ankara 2003; Rıza Karagöz, Canikli Ali Paşa, TTK Yayınları, Ankara 2003.

${ }^{26}$ T.Ş.S., nr. 1902,vr. 110a, (evahir-i C.Evvel 1149).

${ }^{27}$ T.Ş.S., nr. 1902, vr. 120b, (evail-i Zilhicce 1149).

${ }^{28}$ T.Ş.S., nr. 1903, vr. 134a, (22 R.Evvel 1150).

${ }^{29}$ T.Ş.S., nr. 1903, vr.135b (C.Evvel 1150) ve vr. 142a, (C.Evvel 1150) Bu hükümde Üçüncüzade Ömer, Trabzon ayanından olarak tanımlanmaktadır; Aynı Defter, vr. 154a, (Şevval 1150): bu kayıtta konu yine imdad-ı seferiye tarhı iken Üçüncüzade Ömer, ilk hükümde sadece Trabzon sükkanından olarak ifade edilmişken ardı sıra gelen hükümde Ömer Ağa olarak kayda geçmiştir.

${ }^{30}$ T.S.S.S., nr. 1903, vr.194a(15 C.Evvel 1150).
} 
ma 'iyyetine bir sâ 'at mukaddem irsâl ve îsâl eylemek" ifadesi yer almaktadır. ${ }^{31}$ Aynı defterin devam eden iki hükmünde ise yukarıda adını zikrettiğimiz Fatsalı Hacı Ahmed'e karşı Üçüncüzade'nin harekete geçmesi istenmekteydi. Zira Hacı Ahmed, altı adet çeşitli bölüklerin yoldaşlarıyla birliktelik kurup "ni 'met-i pâdişâhî ile perverde iken hakk-ı ni meti bilmeyüp ve üzerlerine lâzım olmayacak sözlerden ictinâbları olmaduğundan umûr-ı mühimmenin te 'hîrine bâ is ve nâ-marzi hareketleri zuhûr eyledüğü" şeklinde belirsiz bir suçlamanın konusu olmuşlardı. Muhtemelen yukarıdaki hükümle bağlantılı olarak asker sevkiyatı ve temini için bu isimler gerekli hassasiyeti göstermemişti. Ömer'den istenen bunların bir an önce yakalanıp Samsun kalesinde hapsedilmelerine yardım etmesiydi. ${ }^{32}$ Fatsalı Hacı Ahmed ile Üçüncüzade Ömer arasındaki gerilimin başlangıcını bu hadiseye bağlamak doğru olacaktır. Ömer Paşa'nın idamına giden süreçte de bu ikili arasındaki ilişki önemli rol oynamış gözükür. Paşa'nın idam edildiği dönemde reisülküttab vazifesinde olan Koca Ragıb Efendi'nin telhislerinden birinde buna temas edilir. ${ }^{33}$

Onun görev manzumesindeki bu değişiklik ve önemli meselelerde ön plana çıkmaya başlamasını 1737 yılının sonu olarak tespit etmek mümkündür. Bu dönemde Üçüncüzade Ömer artık "ber-vech-i malikane Canik sancağl muhassillı̆ğ" görevindedir. Üstelik bu görevi henüz altı ay önce merkezi idarenin kendisinden yakalamasını istediği Fatsalı Hacı Ahmed ile birlikte yürütmektedir ${ }^{34}$. Kendisinin bu göreve ne zaman atandığına dair bir veri tespit edemedik. Şubat 1738 tarihli bir mühimme hükmünde Üçüncüzade Ömer ve Fatsalı Hacı Ahmed'e, kethüdaları Küçük Ali'ye taarruz eden eşkıyadan Alaybeyioğlu Derviş'in ele geçirilip cezasının verildiği bildirilmiş, ayrıca onlardan Canik sancağının kazalarında ortaya çıkıp asayişi bozan, zahire, donanma kalyonları için kereste, sefer tedarikinde deve gibi miri ihtiyacın yerine getirilmesi için kazaların hissesine düşen paranın ve Sivas valisinin imdad-ı seferiyesinin toplanmasına engel olan sair eşkıyanın da bulundukları yerde ele geçirilip ortadan kaldırılmaları istenmiştir. ${ }^{35}$ Aynı defterde aynı tarihli hükümlerde Canik sancağı muhassılı olan Ömer'den "mukaddema Görele Voyvodası" olarak bahsedilmekte ve kendisinden bir dizi işi yerine getirmesi talep edilmekteydi. Bunlar, donanmada bulunan kalyonlar için Canik sancağı kazalarından tel mubayaa edilmesi, Gümüşhane ve Kürtün havalisinde ahaliye zarar veren eşkıyanın ortadan kaldırılması, yollardaki asayiş ile birlikte madencilerin ve yolcuların emniyetinin sağlanması, Gümüşhane ve Espiye madenleri için gerekli olan kömür ve diğer malzemenin tedarik edilerek gönderilmesi, Espiye ve havalisinde bulunan madenlerin civarı dağlık ve öteden beri "şekavetle meşhur" Çepni eşkıyasının köyleri olduğundan bu köyler arasından geçen yollarda nice madenci ve yolcu haksız yere katledilerek yolların emniyetsiz hâle gelmesinden dolayı asayişin sağlanması, eşkıyanın

\footnotetext{
${ }^{31}$ BOA.A.DVNS.MHM.d., nr. 143 hüküm no: 236 (Evasit-1 Cemaziyelevvel 1150).

32 Aynı Defter, hüküm no: 237 ve 238 (Evahir-i Cemaziyelevvel 1150-Eylül 1737) ve BOA.A.DVNS.MHM.d., nr. 144, hüküm no: 604(evahir-i Cemaziyelevvel 1150).

${ }^{33}$ H.Abdulkadir Özel, Koca Ragıb Mehmed Paşa'nın Münşeat ve Telhisatı, Değerlendirme-Metin, (Mimar Sinan Güzel Sanatlar Üniversitesi Sosyal Bilimler Enstitüsü Yayımlanmamış Yüksek Lisans Tezi), İstanbul 2014, s. 165-167. Bkz. Dipnot:52.

${ }^{34}$ Canik Muhassıllığg avarız ve nuzül bedeli gelirlerinin H.1154 ve 1155 'te ber-vech-i malikane Fatsalı elhac Ahmed Ağa ile Üçüncüzade Ömer Paşa’nın üzerinde olduğunu gösteren hesap defteri için bkz. BOA., D.BŞM.MLK.d., nr. 14115 ve ayrıca Üçüncüzade Ömer Paşa'nın katlinden sonra muhassıllığa dair yapılan tadilat ve muhasebe hakkında tafsilat için bkz. BOA., C.ML, nr. 318-13058(7 Zilkade 1157-12 Aralık 1744).

${ }^{35}$ BOA., A.DVNS.MHM.d., nr 145, hüküm no: 114 (Evahir-i Şevval 1150).
} 
üzerine gidilerek ortadan kaldırılması ve civar kazalara firar edecek eşkıyanın da bulunduğu yerde cezasının verilmesi idi. ${ }^{36}$

Bu tür bölgesel-yerel meselelerle yerel bir yönetici olarak ilgilenen Üçüncüzade Ömer'in 1738 yılının ortalarına doğru imparatorluğun farklı bir bölgesindeki eşkıya hareketine engel olması için görevlendirildiğini görüyoruz. Bu görev, Aydın yöresinde ortaya çıan ve devleti uzun yıllarca uğraştıran levent bölükbaşısı Sarıbeyoğlu Mustafa'nın eşkıyalık faaliyetlerinin önlenmesidir. ${ }^{37} 145$ numaralı Mühimme Defteri'nin farklı hükümlerinde ${ }^{38}$ bu meseleyle ilgili Üçüncüzade Ömer'e emirler gönderilmişti. Bunlardan ilki, Nisan 1738'de Sarıbeyoğlu eşkıyasına karşı serdar atanan vezir Ahmed Paşa'ya kendisinin emrindeki askerlerle yardım etmesine dairdir. İmparatorluğun Batı Anadolu bölgesindeki bu huzursuzluğun giderilmesinde Üçüncüzade Ömer'in çabası belgelere yansıdığı kadarıyla karşılıksız bırakılmamıştır. Artık "rütbe-i mirimirani ile şanı terfi kılınan Üçüncüzade Ömer" ifadesi belgelerde karşımıza çıkar. Yine belgelerin diliyle "zatındaki şecilik ve bahadırlık ve iş uhdesinden gelmeye kadir olmak" hususiyetlerinden sayılır. ${ }^{39}$ Bütün bunlar sayllıp beylerbeyilik rütbesi kendisine verilirken devletin isteği yine öne çıkarılmış ve beş yüz kadar leventi tahrir ederek kırk güne kadar Sarıbeyoğlu üzerine gönderilen Ahmed Paşa'nın maiyyetinde bulunmak şartı ifade edilmiştir. Bu arada Canik muhassıllığı görevine devam eden ve beylerbeyilik unvanı alan Üçüncüzade Ömer'e Karahisar-1 Şarki sancağının da "ber vech-i arpalık" tevcih olunduğu görülmektedir. ${ }^{40}$ Onun

Volume 12 Issue 6

December 2020

36 BOA., A.DVNS.MHM.d., nr 145, hüküm no: 186 ve 187 (Evahir-i Şevval 1150) ve BOA., A.DVNS.MHM.d., nr. 146, hüküm no: 73 (10 Muharrem 1151). Yaklaşık aynı dönemde Üçüncüzade Ömer, Görele kadısına gönderilen ve bölge reayasının haksız vergi talebinden şikayet ettiği bir belgede Trabzon sancağında vaki paşa haslarından "mahsul-i beytü'l-mal ve gayri maktuu"unun ber vech-i malikane iki ortağından biri pozisyonundadır, bkz. T.Ş.S., nr. 1903, vr. 154b, (19 Zilhicce 1150-9 Nisan 1738). Bu malikane sahipliği Trabzon valiliği görevindeyken de devam etmektedir, bkz. T.Ş.S., nr. 1906, vr. 89a(3 Receb 1153-24 Eylül 1740).

${ }^{37} \mathrm{Bu}$ eşkıyalık faaliyeti hakkında ayrıntılı çalışmalar yapılmıştır, bkz. Çağatay Uluçay, 18. ve 19. Yüzyıllarda Saruhan'da Eşkıyalık ve Halk Hareketleri, İstanbul 1955; Necmi Ülker, Sarıbeyoğlu Mustafa ve Faaliyetleri 1735-1739, İstanbul Üniversitesi Edebiyat Fakültesi Tarih Bölümü Mezuniyet Tezi, İstanbul 1964; Aynı Yazar, “Sarıbeyoğlu'nun İzmir'e Yürüyüşü ve Avrupalı Tüccarlar”, Tarih Incelemeleri Dergisi, Cilt: 4 Sayı:1, İzmir 1989, s. 43-51; Mehmet Yaşar Ertaş, “18. yüzyılda Bir Osmanlı Eşkıyası: Sarıbeyoğlu Mustafa”, Uluslararası Denizli ve Çevresi Tarih ve Kültür Sempozyumu Bildiriler I, Denizli 2007, s. 399-411; Hakan Karagöz, "Bir Alman Kaynağının İzlenimlerine Göre Sarıbeyoğlu İsyanı ve Batı Anadolu'daki Etkileri”, Süleyman Demirel Üniversitesi Fen Edebiyat Fakültesi Sosyal Bilimler Dergisi, (Prof. Dr. Kemal Göde Armă̆an Sayısı), Isparta 2013, s. 193-215.

${ }^{38}$ BOA., A.DVNS.MHM.d., nr 145, hüküm no: 499 ve 517 (Zilhicce 1150); hüküm no: 1128 ve 1150 , (Evahir-i Şaban 1151- Aralık 1738): bu hükümlerde Sarıbeyoğlu eşkıyasına karşı Ahmed Paşa emrine 500 levent götürmesi istenmiştir. Daha sonra bu sayı üç binden fazla harbe kadir olarak asker olarak artırılacaktır. Trabzon siciline yansıyan kayıtlarda ise bu tarihten birkaç ay önce Ömer'den Trabzon mevcudundan Aydın bölgesine 1150 vukiye barut ihracının ve çeşitli zehayirin sevkinde görev almasının istendiğini görüyoruz, T.Ş.S., nr. 1903, vr. 163a, (Safer 1151-Haziran 1738).

Ayrıca 146 numaralı mühimme defterinde Üçüncüzade Ömer' in isminin geçtiği hükümlerin neredeyse tamamı bu konuyla ilgilidir, bkz. BOA., A.DVNS.MHM.d., nr 146, hüküm no: 149, (10 Safer 1151), hüküm no: 209-212-217-224-244, (Temmuz-Ağustos 1738). Ayrıca perakende evrak için bkz. BOA, C.DH, nr. 227-11307, (Evahir-i Ca. 1151) ve BOA, C.AS, nr. 1111-49207, (Zilkade 1151).

${ }^{39}$ BOA., A.DVNS.MHM.d., nr 145, hüküm no: 1163 (Evail-i Ramazan 1151-Aralık 1738) ve hüküm no: 1578, (Zilhicce 1151)

40 "Zatında olan maye-i gayret ve hamiyet ve basiret", Aynı Defter, hüküm no: 1762, (Evasit-1 Muharrem 1152-Nisan 1739). Bu hükümde beylerbeyilik unvanının verilmesinde ve Karahisar-1 Şarki sancağının tevcihinde nelerin rol oynadığı ayrıntılarıyla ifade edilmektedir. Bunlara nazar olunduğunda temel argüman olarak Sarıbeyoğlu eşkıyalığına ve Canik'teki eşkıyalık faaliyetlerine karşı Üçüncüzade Ömer' in 
bulunduğu yerden hareket edip görev yerine giderken yolda sefere memur olup geri kalan yeniçeriler ve diğer askerler var ise uygun iskelelerden Kırım tarafına sevkinin yanında Sinop ve Trabzon iskelelerinde hazırlanan zehayir ve cephanenin de yine Kırım'a gönderilmesinde görevlendirildiğini anlıyoruz. ${ }^{41}$

1739 yılının sonları ve 1740 yılının başları Üçüncüzade Ömer'in hayatında bir dönüm noktasını teşkil etmiştir. Yukarıda bahsettiğimiz gibi önce mirimiranlık rütbesi verilen Ömer, daha sonra Canik muhasıllığı ile birlikte Karahisar-1 Şarki'nin tasarrufunu da uhdesine almıştır. $\mathrm{Bu}$ terfide sicil ve mühimme kayıtlarına göre eşkıyalığın önlenmesine karşı faaliyetleri (Sarıbeyoğlu ve Canik'teki) ile Kefe'ye asker ve zehayir naklindeki başarısı önemli bir rol oynamıştır. Nihayet Trabzon eyaletine vali atanmadan hemen önce kendisinden bu bölgedeki eşkıya ve haramzadeleri yakalaması, ellerindeki silahlarını toplaması ve bunların defterini tutması istenmiştir. ${ }^{42}$

Bu yoğun tempolu görevlerden sonra Kasım 1739 'da Trabzon valiliği görevine başlayan Üçüncüzade Ömer'den öncelikli olarak talep edilen eşkıya ile mücadele, Gümüşhane madenlerine nizam verilmesi ${ }^{43}$ ve hususiyle İran seferleri takribiyle Erzurum, Kars, Ahiska civarlarına cebehane ve zahire nakli keyfiyetidir. Gerçekten de Üçüncüzadenin Trabzon valiliğinin ilk yılına denk düşen hükümlere baktığımızda bu durum açıkça tebarüz eder. ${ }^{44}$

Üçüncüzade Ömer bu şekilde Trabzon valiliğinde ilk elden eşkıya gruplarına karşı mücadele emirlerini alırken diğer yandan kendisine bir saray inşasına karar vermiş, vali atanmasından hemen sonra başladığı Güzelhisar'ın etrafindaki evlerin istimlaki için de merkezin görüşüne başvurmuş ve sarayı ile ilgili işlemlere dair İstanbul'un onayını aramıştır. ${ }^{45}$ Trabzon kadısı Mustafa Efendi'nin arzı ile çıkan hükümden anlaşıldığı kadarıyla Üçüncüzade Ömer, mahkemeye başvurarak İskenderpaşa mahallesi mülhakatından olup derya kenarında kayalık üzerinde yükselen ve Frenkhisarı olarak bilinen bölgenin çoğu evinin harap halde bulunduğunu, sahiplerinin tamire kudretleri olmadığını, bölgenin yalı olarak bilinen bir bölge hususiyeti gösterdiğinden bu bölgedeki yirmi sekiz adet mülkü, sahiplerinin rızaları çerçevesinde satın aldığını haber vermişti. Onun istediği kadı aracilığıyla "binaya müsaade-i hümayun"du, bu müsaade Saray-1 Hümayun tarafindan verilmişti. Gerçekten de Üçüncüzade Ömer vekili Musa Ağa aracılığıyla âdeta yaptıracağı bina için istimlake girişmişti. ${ }^{46} \mathrm{Bu}$ şekilde literatürde yer alan Paşa'nın saray inşası ve bu inşa üzerinden devlete karşı gelme iddialarının da asılsızlığı arşiv belgeleri dolayısıyla tespit edilebilmiştir ${ }^{47}$.

\footnotetext{
hizmetlerinin belirgin rolü olduğu görülür. Bu tarihte bir başka hükümde Üçüncüzade Ömer ilk kez paşa unvanıyla ve aynı konuyu muhtevi bir hükümde ismi geçer, bkz. Aynı Defter, hüküm no: 1792, (1 Muharrem 1152-10 Nisan 1739).

${ }^{41}$ BOA., A.DVNS.MHM.d., nr 145, hüküm no: 1889, (evahir-i Safer 1152-Haziran 1739) ve BOA, C.DH, nr. 57-2821, (Evasit-1 Ra 1152) krş. T.Ş.S., nr. 1905, vr. 32a(Safer 1152).

42 T.Ş.S., nr. 1905, vr. 36a-1/2(Evahir-i Rebiyülevvel 1152).

${ }^{43}$ T.Ş.S., nr. 1905, vr. 36b(Evail-i Şaban 1152).

${ }^{44}$ Birkaç örnek için bkz. BOA., A.DVNS.MHM.d., nr 147, hüküm no: 224(Evail-i Şevval 1152-Ocak 1740); Aynı Defter, hüküm no: 424(Evasit-1 Muharrem 1153-Nisan 1740); Aynı Defter, hüküm no: 860(Evahir-i Cemaziyelevvel 1153-Ağustos 1740) vd.; T.Ş.S., nr. 1906, vr. 89a-b, 90a-b, 92a vd.(Cemaziyelahir 1153Eylül 1740).

${ }^{45}$ T.Ş.S., nr. 1905, vr. 45b-46a(Evahir-i Safer 1153-Mayıs 1740).

${ }^{46}$ Miraç Tosun, Şeriye Sicillerine Göre Trabzon'da Mülk Satışları 1148-1735/1153-1741, (KTÜ Sosyal

Bilimler Enstitüsü Yayımlanmamış Yüksek Lisans Tezi), Trabzon 2005, s.47 vd.

${ }^{47}$ Mahmut Goloğlu, Trabzon Tarihi, Serander Yayınları, Trabzon 2013.
} 
Bütün bunlarla birlikte, henüz valiliğe atanmasından dokuz ay geçmeden Üçüncüzade'nin bir teftiş geçirdiğini görüyoruz. Üçüncüzade Ömer Paşa'nın hakkındaki ithamları teftiş için İstanbul'dan mübaşir tayin edilen Yusuf ile Trabzon eyaletindeki kadılara hüküm gönderilmişti. ${ }^{48}$ Ömer'in hüsn-i haline dair Trabzon eyaletindeki kadılardan arzlar ve ahaliden mahzarlar gelirken diğer yandan İstanbul'dan gelen yazıda, "su-i halini mutazammın rikab-l hümayuna dahi arzuhal ile ruka-i iş̧tikalar olduğundan keyfiyetde iştibah vaki olmağla künh ve hakikati malum olmak murad-ı hümayunum olmak hasebiyle" ifadesi bulunmakta ve "sırren ve alenen kaza-be-kaza teftiş ve tefahhus" olunmas1 ve bildirilmesi istenmekteydi. Bu yapilırken izlenen yöntem, "buğzdan ari, mevsuku'l-kelam, mutemet" kişilerden durumun sorulmas1, böylece her iki tarafin sldk ve kizbinin belirlenmesi idi. Sadece bu teftiş ile de yetinilmemesi ve bundan sonra da sirren ve alenen tecessüs olunması, padişahın olayın künh ve hakikatine sahip olması isteği ifade edilmişti. Hemen aynı zaman diliminde Paşa'nın başta Güzelhisar'daki sarayı, Görele'deki çeşitli mülkleri için ${ }^{49}$ evladiyelik vakıf kurmasını bu teftişin yansıması olarak da okumak mümkündür.

Rumeli payesiyle Trabzon valiliği Şubat 1741 'de ibka k1lınan ${ }^{50}$ Ömer Paşa üç ay sonra ise merkezi idare tarafından son görev yeri olan Van kalesi muhafızlığına atanacaktı. ${ }^{51}$ Bunu haber verdiği buyuruldusunda tekrar Trabzon'a dönene kadar mütesellimlik görevine Osman Bey’i atadığını bildirecekti. Trabzon valiliği görevine devam eden ancak artık şehirde bulunmayan Ömer Paşa, bir süre sonra Trabzon valiliğinden azlini isteyecek bir durumda kendini bulacaktı. Zira yazdığı buyrulduda ifade ettiğine göre "Trabzon ayanlarının hile-i melanet üzere olanlarının eyledikleri melanetlerinden naşi zabt ve rabtına mani olduklarından sancağ-ı mezburun üzerimizden ref içün bi'd-defaat Devlet-i Aliyye'den rica olunduğuna binaen" ifadesi yer alıyor, bu ayanların mütesellim tayin ettiği yeğeni Osman Bey'e de iş yaptırmadıklarından kendisine ait gelirlerin toplanamadığından, ayan-1 vilayetin işe karıştırılmaması gereğinden şikayet ediyordu. Ancak mansıbından azli isteği kabul görmemişti. ${ }^{52}$ Ömer Paşa, yeğeni Osman Bey'i Trabzon mütesellimliği görevini yürütürken gördüğü lüzum üzerine Van'da yanına almış, bu kez ise aynı göreve kardeşi Osman Bey'i atamışt1. ${ }^{53} \mathrm{Bu}$ atamadan hemen sonra ise Veli Paşa'nın Trabzon

${ }^{48}$ BOA., A.DVNS.MHM.d., nr 147, hüküm no: 891 ve T.S.S., nr. 1906, 88b (Evahir-i CemaziyelevvelAğustos 1740)

${ }^{49} \mathrm{Bu}$ vakfiyenin ayrıntıları için bkz. Necmettin Aygün, a.g.m., s. 47-49.

${ }^{50}$ T.Ş.S., nr. 1906, vr. 97a, (Zilhicce 1153)

51 T.Ş.S., nr 1906, vr. 99a, (27 Safer 1154-14 Mayıs 1741). Bu atama ilgili tarihten biraz daha evvel olmalıdır, zira 2 Mayıs 1741 tarihli bir fermanda Trabzon alaybeyinin bayrağı altında zuema ve erbab-1 timarının toplanması ve Van'a gönderilmesi istenmişti, bkz. T.Ş.S., nr. 1906, vr. 99b; Ayrıca bkz. Ömer Paşa'nın Van'a giderken yapacağı masrafların Trabzon sancağının hangi kazasından ne kadar toplanacağına dair imdad-1 seferiye akçelerini gösterir liste: Aynı Defter, vr. 114b(28 Muharrem 1154-15 Nisan 1741) ve Ömer Paşa'nın Van'a azimetinden sonra vaki olan vilayet masraf listesi: Aynı Defter, vr. 111b(3 Rebiyülevvel 1154-19 Mayıs 1741).

52 T.Ş.S., nr. 1906, vr. 109b ve 110a, (11 Cemaziyelahir 1154-24 Ağustos 1741).

Reisülküttab Ragıb Efendi'nin telhisinden Trabzon ayanından olarak nitelendirdiği kişilerin Fatsalı Ahmed Ağa ve adamları olduğu anlaşılıyor: "Paşa-yı mûmâ-ileyhün evvel emirde mütesellimi ve ba"dehu karındaşı ile Fatsalı Ahmed Ağa'nun avene vü teb'asınun beynlerinde vukû‘ bulan mefsedet ve bundan böyle icrâsı dâ'iyesinde oldukları habâset ü şekâvet bi'l-cümle ma'lûm-1 dakâyik-mersûm-1 zıllullâhîleri olmışdur”, bkz. H.Abdulkadir Özel, a.g.t., s. 166.

53 T.Ş.S., nr. 1906, vr. 49a(14 Ramazan 1154-23 Kasım 1741). Ömer Paşa'nın kardeşi Osman Bey, mütesellimlik görevinden evvel Batum sancağını yurtluk-ocaklık olarak tasarruf ediyordu, bkz. T.Ş.S., nr. 1906, vr. 93b(4Zilkade 1153-21 Ocak 1741). Yine Canik Muhassıllığını Ömer Paşa ile birlikte yürüttügünü ve Görele voyvodalığında bulunduğunu hatırlatalım, Osman Bey’in asıl bilinirliğini Ömer Paşa'nın 
valiliği görevine getirildiğini ${ }^{54}$ ve bu suretle Ömer Paşa'nın valilik görevinin Kasım 1741'de sona erdiğini söyleyebiliriz. Her ne kadar Trabzon valiliği görevi sona ermiş, Van muhafızlığı görevi devam etse de bu görev sırasında Ömer Paşa'yı Trabzon'la oldukça bağlantılı çok başka bir pozisyonda görüyoruz: Trabzon'un en büyük vakıf kurumu olan İmaret-i Hatuniye Vakfı'nın tevliyeti ve cibayeti ${ }^{55}$. Bu durum onun görev skalası açısından oldukça ilginç bir yerde durmaktadır, ancak kariyer basamaklarındaki gelir kaynaklarının idaresinin(voyvodalıkmuhasıllık-malikane sahipliği) yadsınamaz yeri hatırlandığında pek de şaşılacak bir şey olmadığı görülecektir.

Son olarak Ömer Paşa'nın ölümüne gelinecek olursa ilk sual elbette onu bu ölüme götüren sebeplerin ne olduğudur. Kasım 1741 tarihi ile ölüm tarihi olan Ekim $1742^{56}$ arasında Van beylerbeyliği görevinde bulunan Paşa'nın gerek Trabzon'da gerekse Van'da yerel güç unsurlarıyla çatışmasının onu idama götüren saikler olduğu söylenebilir ${ }^{57}$. Ayrıca Mühimme Defterindeki hükümlere göre halka zulmetmesi, devlet hazinesine hıyaneti ve adamlarının şehir içindeki uygunsuz hareket ve tavırları onu idama götürmüştür ${ }^{58}$. Osmanlı arşivindeki müteferrik evraktaki bilgilerden hareketle paşanın idamında Hatuniye vakfi köylerinden zorla toplanan

idamından sonra Paşa'nın muhallefatına dair ortaya çıkan ve yıllara yayılan evrak sağlayacaktır, bu hususla ilgili bkz. N. Aygün, a.g.m., s. 54-69.

${ }^{54}$ T.S..S., nr. 1906, vr. 84a(13 Ramazan 1154-22 Kasim 1741).

${ }^{55} \mathrm{Bu}$ görevlere ait berat kayıtları: T.Ş.S., nr. 1906, vr. 74b-1, 74b-2(22 Zilhicce 1154-28 Şubat 1742). Paşa bu göreve daha önce getirilmiş olmalıdır, zira vakfın cami, medrese, imaret ve su yollarının tamiri için mahkemeye gelerek keşif isteğinde bulunduğu kayıtlardan anlaşılmaktadır, bkz. Aynı Defter, vr. 20a, (1 Safer 1154-18 Nisan 1741).

${ }^{56}$ Paşa'nın idamından sonra terekesin in tespitine dair ilk yazışmalardan biri 18 Şaban 1155/18 Ekim 1742 tarihlidir, bkz. T.Ş.S., nr. 1907, vr. 166a; Ayrıca bkz. BOA., C.DH, nr. 341-17027(29 Şaban 1155-29 Ekim 1742): “Bundan akdem ba-ferman-ı ali cezası tertîb olunan Üçüncüoğlu Ömer Paşa'nın ser-i maktuı ve bazı mühim tahrirat ile gelen mübaşir..."

${ }^{57}$ Trabzon' daki bazı ayan gruplarıyla olan çatışmasını zikretmiştik. Van için ise bkz. BOA., C.DH., nr. 522563, (13 Rebiyülevvel 1155-18 Mayıs 1742); BOA., C.DH, nr. 197-9832(25 Rebiyülevvel 1155). Özellikle Hakkari Hakimi İbrahim ile olan çatışması zikre değerdir.

58 BOA, A.DVNS.MHM.d, nr. 149, hüküm no: 249(Evasıt-1 Şaban 1155): “....Van beylerbeyisi olan Üçüncüzâde Ömer Paşa mecbûl olduğu habîs tıyneti muktezâsınca Van'a vusûlünden bu âna değin re 'ayâa fukarâsına ve ibâdullâha eylediği cevr ü zulmü merreten ba'de uhrâ egerçe istid 'â olunup merkûm belki kabûl nush ü pend ile etdiği ef'âl-l şenâ 'atden tevbe ve rucû 'eder mülâhazasiyla bu vakte değin te'dîb ve gûşmâli ihmâl ve te 'hîr ve keyfiyyet-i hâlini sirren tefahhus içün mahsûs adam ta 'yîn ve tesyîr olunmuşidi. Bu def'a vârid olan tahrîrâtınızda paşa-yı merkûmun irtikâb etdiği mefâsid ve mel 'anet ve husûsen cânib$i$ mîrîye olan hasâret ve hıyâneti ne mertebelere resîde olduğu mufassalen tahrîr ve takrîr olunmağla, mantûk-ı tahrîrât hakkında mesmû' olan hâlât ve keyfiyyâta muvâfik ve mutâbık olduğuna binâ'en bilâşekk karîn-l sihhat ve yakîn olmuşdur. Fî mâ-ba'd mezbûrdan tevbe ve rücû'ile salâh-ı hâle meyl ve rağbet bir dürlü mutasavver olmayup, i 'dâm ve izâlesi Devlet-i aliyye'me ve ibadullâha nâfi 'idüğü zâhir ve âşikâr olmak hasebiyle sadr-ı a 'zam kâ 'imesinde ifâde olunduğu üzre bilâ-emân cezâsı tertîb ser-i maktû ' rikâbı kâm-yâbıma irsâl ve tesyîr olunmak fermânım olmă̆ıı..."

Aynı Defter, hüküm no: 250: "Fukarâ-yl ra 'iyyete hezâr gûne cevr ü te 'addîye cesâreti ve cânib-i mîrîye hasâret ve hıyâneti zâhir olup, $i$ 'dâm ve izâlesi hem ibâdullah ve hem Devlet-i Aliyye'me nâfi 'olmakdan nâşî cezâsı tertîb olunan Van muhâfizı Üçüncüoğlu Ömer Paşa....”

Aynı Defter, hüküm no: 331, Evahir-i Şevval 1155): “Üçüncüzâdenin levendât ve ağvât makûleleri, paşalara mahsûs olan serâyin ve hânlarda tavtîn olunmayup, kadîme mugâyir mahalle arasında ibâdullâhın menzillerine kondurulup ve ahâlîden ve asâkirden müdde 'î arz-ı hâl verdiğin on guruş da 'vâa ancak elli guruş ve yüz guruş mübâşiriyye alınup ve ibâdullâhın bağçe ve tarlalarına atlar naklolup ve saman ve otlak celbi içün karyelere gitdikde re 'âyâ fukarâsına dürlü dürlü cevr ü eziyet..." 
emval ile Paşa'nın işletmecisi olduğu Yavebolu-Görele reayasına adamlarının müdahalesi sebep olarak sayılabilir. ${ }^{59}$

Ömer Paşa'nın katledildiği sırada sadrazam olan Hekimoğlu Ali Paşa'nın da olaydaki dahli yadsınamaz; onun idamıyla Ali Paşa'nın, bölgedeki karışık durumu (özellikle farklı çıkar gruplarının mücadelesi tahtında) hal yoluna sokmaya çalıştığı söylenebilir. Ancak yaklaşık on yıl sonra, Hekimoğlu Ali Paşa, kendisini Trabzon ayan ve mütegallibesini tedip etmek zorunda olduğu bir görev emriyle -iki kez sadrazamlık makamında bulunan bir idareci sıfatıylaTrabzon'a vali olarak atanmış bulacaktır. ${ }^{60}$

Ömer Paşa'nın idamından sonra mühimme hükümlerinden, mali ahkam kayıtlarından, sicillerden ve müteferrik evraktan anlaşılan Osmanlı bürokrasisini uğraştıran en önemli mesele Paşa'nın geniş bir coğrafyaya ve yekuna ulaşan geriye bıraktığı malları ile alacak ve borçluları meselesidir. Paşanın geriye bıraktığı mal varlığı, Trabzon sicili ve Başmuhasebe Muhallefat Defterinden ortaya konmasına rağmen ${ }^{61}$ bir ana kaynak gözden kaçmıştır. Bu da Maliyeden Müdevver Defterler tasnifinde 9950 numarada kayıtlı bulunan Kuyud-ı Mühimmat Defteridir. Bu defter, arşiv defterlerinin katalog zaafiyetinin araştırmacılara yaşattığı zorluğun bir örneğidir denilebilir. Kuyud-ı Mühimmat Defterleri ${ }^{62}$ de bu durumun bir sonucu olarak göz ardında kalan bir seriyi oluşturmuştur. Bu defterler iki cilt hâlinde düzenlenmiş, birinci cildi Başmuhasebeyi ilgilendiren tezkire kayıtlarına ikinci cildi ise müessese kayıtlarına tahsis edilmiştir. Bu müessese kayıtlarında son kalem Muhallefat idi. İşte MAD 9950 numaralı H. 1155 tarihli cild-i sani kuyud1 mühimmat defterinin içerisindeki belgelerden Ömer Paşa'nın borçları-alacakları ve Trabzon'dan Sivas'a Samsun'dan Şebinkarahisar, Tirebolu, Görele ve Gümüşhane'ye kadar oldukça geniş bir alandaki metrukatının/borç-alacaklılarının kayıtları tespit edebilecektir ${ }^{63}$. Böylece Paşa'nın mal varlığına çok daha geniş bir pencereden bakma firsatı doğacaktır. Yine başka bir kaynak grubu olan- Topkapı Sarayı Arşivinde bulunan ve Harc-ı Hassa Defterleri şeklinde tasnif edilen- bir defterdeki kayda göre ki bu defter H.1156 Muharreminde Hazine-i Enderun-ı Hümayuna dâhil olub irad olunan ecnas-ı nükud ve eşya ve sairdir şeklinde

${ }^{59}$ BOA., C.ML, nr. 171-7236(5 Zilkade 1155-1 Ocak 1743): Maktul Ömer Paşa Kale-i Van'a azimet eyledikde harç-1 rah namıyla evkaf-ı mezbure kuralarından zulmen ve cebren 50 bin kuruşdan ziyade akçe taleb..., hayatında cevr ve teaddisi hadden birun"; Malikane vechiyle mukataası uhdesinde olan Ömer Paşa'nın adamları tarafından Yavebolu ve Görele reayasına yapılan zulmün engellenmesi için bkz. BOA., C.DH, nr. 287-14324, (17 Zilkade 1154-24 Ocak 1742).

${ }^{60}$ M. Tosun, "XVIII. Yüzyıl Ortasında Bir Trabzon Valisi: Hekimoğlu Ali Paşa”, $23^{\text {rd }}$ Symposium of The Comite International des Etudes Pre-Ottomanes et Ottomanes(CIEPO), Sofia, 11-15 September 2018. Basılmamış Bildiri.

${ }^{61}$ N.Aygün, a.g.m. Paşa'nın 1907 numaralı Trabzon sicilindeki ve Başmuhasebe Muhallefat defterindeki muhalellefat kayıtlarını inceler. Burada bir husus üzerinde de durmak gerekir, Ömer Paşa'nın unvanı arşiv kataloglarına çok farklı şekillerde kaydedilmiştir. Misalen İsakcızade Ömer(BOA., C.DH, nr. 227-11307); Uncuoğlu Ömer Paşa(BOA.,D.BŞM.MHF, nr.34-1); Uncuzade Ömer Paşa(BOA., D.BŞM.MHF nr. 34-57, 34-66, 34-76). Arşiv araştırmasının en önemli engellerinden birinin katalogların düzensizliği olduğu bir kez daha tebellür eder.

$62 \mathrm{Bu}$ Defterlerin önemi hakkında öncü bir çalışma için bkz. İdris Bostan, "Kuyud-1 Mühimmat Defterlerinin Osmanlı Teşkilat Tarihi Bakımından Önemi”, Osmanl-Türk Diplomatiği Semineri Bildiriler, İstanbul 1995, s. 143-163.

${ }^{63} B O A, M A D$, nr. 9950. Bu defterdeki kayıtların değerlendirilmesi başka bir araştırmanın konusu olacaktır. Ayrıca Paşa'nın mal varlığı, devlete olan borçları devlet bürokrasisinin çok farklı tasniflerde kayıtlar oluşturmasına neden olmuştur ve bu çok başka bir araştırmayı haketmektedir. Onun terekesinden 100.000 kuruşun Şark seferinde kullanılmak üzere Erzurum ordu defterdarının emrine verilmesi $B O A$., $M A D$, nr. 9944, s. 150, 23 Zilhicce 1155/18 Şubat 1743) ve Faş kalesindeki muhafizların mevaciblerinin ödemesinde kullanılması(BOA., MAD, nr. 9944, s. 104 ile BOA., AE.SMHD.I, nr. 186-14435) önemli örneklerdendir. 
başlıklandırılmıştır- bu başlığın altında maktul Üçüncüoğlu Ömer Paşa'nın eşyasından olmak üzere silahşör-i şehriyari Numan A $\breve{g} a$ kulları yediyle gelen şeklinde Ömer Paşa'nın saray hazinesine aktarılan eşyalarının bir listesi tutulmuştur. Bu listeye nazar olunduğunda ilk maddenin bir cild Mushaf-1 şerif olduğu göze çarpar. Mushaf dışında herhangi bir kitap listede yer almaz. Oysaki Paşa'nın yerelde tutulan terekesinde tasavvuftan fikha kadar 89 cilt kitabı bulunduğu görünmektedir. O terekenin de ilk sırasında bir cilt Mushaf-1 şerif vardır, İstanbul'a gönderilenin bu Mushaf mı başkası mı olduğunu tespit edemiyoruz. Saraya nakledilen eşyasında göze çarpan ilk nokta murassa hançerler, elmasla kaplı altın kuşaklar, zincire merbut zer-i mahbub pareler, külçe gümüşler, yine çoğu gümüşten kuşaklar, at takımları ve giyecek malzemeleri göze çarpmaktadır. Bu kayıtların saray arşivinde iki nüshası bulunmaktadır. Birinci nüsha olan D.4109 defterin müsveddesi gibi durmakta ve her bir parçanın üzerinde muhtemelen saraya intikal tarihini gösteren kayıtlar mevcuttur. Aynı defterin temize çekilmiş bir kopyası gibi duran D.2387'de ise sadece saraya intikal edem malların isimleri ve adetleri yazılmıştır. ${ }^{64}$ Saraya nakledilen emval için gerek gemi gerekse de menzil beygirinin kiralandığını kaynaklar ifade eder ${ }^{65}$. İstanbul'a nakledilenler arasında Kazak köleler ayrı bir bahistir. ${ }^{66}$ Paşa'ya ait iki hisselik Karadeniz şaykasının 2046 kuruşa satıldığı da mali ahkâm defterindeki bir mülknamede yer alır. ${ }^{67}$

\section{Sonuç}

Trabzon gibi dönemin şartları içerisinde önemli bir eyalette valilik makamında oturup akabinde bir serhad ve savaş ucu eyaleti olan Van'da görev yaparken idam edilen Ömer Paşa'nın hayat hikâyesini ve sonrasını kaleme almak bu türlü görece kaynak çeşitliliğinde oldukça güç bir vazife olarak ortada durmaktadır. Bir Osmanlı valisinin görev yaptığı dönemi ve o dönemin sonrasını ortaya koyarken kaynakları mümkün olduğunca çeşitlendirmek ve arşivin geniş dünyasında oldukça dikkatli bir araştırma yapılması gereği ortaya çıkar. Bu tür tarihi şahsiyetlerin faaliyetlerini ele alırken en temel malzememizin Osmanlı belgeleri olduğu bir kez daha kendini gösterir. Yerel idarecilik basamaklarında ilerleyen Ömer Paşa, taşra idaresinin en önemli idari-askeri görevi olan beylerbeylikte ise uzun süre kalamamış, geniş ekonomik networküne karşı kısa zaman içerisinde geldiği konumu sindiremeden vefat etmiştir. Öte yandan Osmanlı dönemi Trabzon valileri arasında sivil bir mimari eser bırakması özelliği ile Ömer Paşa, tarihteki yerini almıştır.

\section{Bibliyografya}

\section{Arşiv Kaynakları}

Devlet Arşivleri Başkanlığı Osmanlı Arşivi, Bab-1 Asafi Mühimme Defterleri Tasnifi= BOA, A.DVNS.MHM.d.57, 143, 144, 145,146, 147, 149.

Devlet Arşivleri Başkanlığı Osmanlı Arşivi, Maliyeden Müdevver Defterler Tasnifi= BOA, MAD. 9944, 9947, 9950.

Devlet Arşivleri Başkanlığı Topkapı Sarayı Müzesi Arşivi Defter Tasnifi= TSMA.D 2387, 4109.

Devlet Arşivleri Başkanlığı Topkapı Sarayı Müzesi Arşivi Evrak Tasnifi= TSMA.E nr. 184-31.

${ }^{64}$ TSMA.D, nr. 4109 ve nr. 2387 ile TSMA.E., nr. 184-31.

${ }^{65}$ BOA., A.DVNS.MHM.d., nr. 57, hüküm no: 219(10 Zilhicce 1155).

${ }^{66}$ BOA., $M A D$, nr. 9944, s.48, (20 Şaban 1155-20 Ekim 1742) ve BOA., C.ML, nr. 746-30374.

${ }^{67}$ BOA., MAD, nr. 9947, s.65, (5 Safer 1156- 1155-31 Mart 1743) ve BOA., C.BH, nr. 209-9776. 
Devlet Arşivleri Başkanlığı Trabzon Şeriye Sicilleri=T.Ş.S. 1901, 1902, 1903, 1904, 1905,1906, 1907

Devlet Arşivleri Başkanlığı Osmanlı Arşivi, Ali Emiri-Sultan I. Mahmud Tasnifi= BOA, AE.SMHD.I nr.160-12050, nr. 186-14435

Devlet Arşivleri Başkanlığı Osmanlı Arşivi, Cevdet-Maliye Tasnifi= BOA, C.ML nr. 171-7236, nr. 318-13058, nr. 746-30374.

Devlet Arşivleri Başkanlığı Osmanlı Arşivi, Cevdet-Dahiliye Tasnifi= BOA, C.DH nr. 52-2563, nr. 57-2821; nr. 197-9832, nr. 227-11307, nr. 287-14324, nr. 341-17027.

Devlet Arşivleri Başkanlığı Osmanlı Arşivi, Cevdet-Bahriye Tasnifi= BOA, C.BH nr. 209-9776.

Devlet Arşivleri Başkanlığı Osmanlı Arşivi,Bab-1 Defteri Başmuhasebe Muhallefat Halifeliği Kalemi Evrak1 Tasnifi= BOA, D.BŞM.MHF nr.34-1, nr. 34-57, nr. 34-66, nr. 34-76

Devlet Arşivleri Başkanlığı Osmanlı Arşivi, Bab-1 Defteri Başmuhasebe Malikane Halifeliği Kalemi Evrakı Tasnifi= BOA, D.BŞM.MLK.14115

\section{Kaynak Eserler ve Araştırma-İ́ncelemeler}

AKYILDIZ, Ali, "İnsanı Yazmak:19. Yüzyıl Osmanlı Biyografi Yazıcılığı ve Problemleri Üzerine Bir Değerlendirme”, Osmanlı Araştırmalarl, Sayı 50, İstanbul 2017, s.219-242.

ALANOĞLU, Murat, "XVIII. Yüzyılda Maktul Bir Osmanlı Veziri: Bağdad Valisi Hafiz Mustafa Paşa (Ispanakçızade) ve Katli Meselesi”, CIEPO 22: Uluslar arası Osmanlı Öncesi ve Sonrası Çalışmaları Komitesi, 4-8 Ekim 2016 Bildiriler Kitabı, ed.K.İnanM.Tosun-D.Çolak, Cilt 2, Trabzon 2018, s. 527-543.

AYGÜN, Necmettin, "XVIII. Yüzyılda Bir Osmanlı Valisi: Üçüncüoğlu Ömer Paşa ve Muhallefatı", Karadeniz Incelemeleri Dergisi, Say1 7, Trabzon 2009, s. 39-77.

BAYATLI, Nilüfer, "Osmanlı Döneminde Bağdad Valileri(1534-1917)", Türk Dünyası Araştırmaları, Say1 158, İstanbul 2005, s.189-202.

BEŞİRLİ, Mehmet, "Trabzon Valisi Hazinedarzâde Osman Paşa ve Zamanı (1827-1842)", Karadeniz Tarihi Sempozyuти I, (25-26 Mayıs 2005), Trabzon 2007, s.397-416.

BİZBİRLIKK, Alpay, "XVIII. Yüzyılda Bir Osmanlı Valisinin Ölümü Ardından Gelişen Olaylar Üzerine", Tarih İncelemeleri Dergisi, Sayı 15, İzmir 2000, s. 171-181.

BOSTAN, İdris, "Kuyud-1 Mühimmat Defterlerinin Osmanlı Teşkilat Tarihi Bakımından Önemi”, Osmanlı-Türk Diplomatiği Semineri Bildiriler, İstanbul 1995, s.143-163.

EMECEN, Feridun M., "Iki Osmanlı Ricalinin Resmi Hayatlarının Kaynaklarına Dair”, Osmanlı Araştırmaları, Sayı 17, İstanbul 1997, s.91-97.

“Osmanlı Kronikleri ve Biyografi”, İslam Araştırmaları Dergisi, Sayı: 3, İstanbul 1999, s.83-90.

ERTAŞ, Mehmet Yaşar, "18. yüzyılda Bir Osmanlı Eşkıyası: Sarıbeyoğlu Mustafa”, Uluslararası Denizli ve Çevresi Tarih ve Kültür Sempozyumu Bildiriler I, Denizli 2007, s. 399-411.

GOLOĞLU, Mahmut, Trabzon Tarihi, Serander Yayınları, Trabzon 2013. 
İNAN, Kenan, “Trabzon'da Yönetici Yönetilen İlişkileri 1643-1656” Osmanlı AraştırmalarıJournal of Ottoman Studies, Sayı 23, İstanbul 2003, s. 22-60.

İNBAŞI, Mehmet, “Trabzon/Batum Eyâleti Valileri (1755-1795)”, A. Ü. Türkiyat Araştırmaları Enstitüsü Dergisi, Sayı 31, Erzurum 2006, s.161-191.

KARAGÖZ, Hakan, "Bir Alman Kaynağının İzlenimlerine Göre Sarıbeyoğlu İsyanı ve Batı Anadolu'daki Etkileri”, Süleyman Demirel Üniversitesi Fen Edebiyat Fakültesi Sosyal Bilimler Dergisi, (Prof. Dr. Kemal Göde Armă̆an Sayısı), Isparta 2013, s. 193-215.

KARAGÖZ, Rıza, Canikli Ali Paşa, TTK Yayınları, Ankara 2003.

KILIÇ, Orhan, "18. Yüzyıl Osmanlı Eyalet ve Sancak Tevcihatının Sistematik Tetkiki”, XV. Türk Tarih Kongresi: Ankara 11-15 Eylül 2006 Kongreye Sunulan Bildiriler, Cilt IV - I Kisım,s.1025-1044.

"18. Yüzy1lda Rumili Eyaleti'ne Yapılan Vali Atamalarının Sistematik Olarak İncelenmesi", Archivum Ottomanicum [ 21st Symposium of the Comite International des Etudes Pre-Ottomanes et Ottomanes ( Ciepo = CIEPO), 7-11 October, Budapest], Say1 33. say1, 2016, s.213-234;

"Batı Karadeniz Kıyısında Bir Osmanlı Eyaleti: Özi/Silistre (İdari Taksimat ve Yönetim)",Karadeniz Incelemeleri Dergisi, Sayı 23, Trabzon, 2017. s. 29-82.

"XVIII. Yüzyılın İlk Yarısında Trabzon Eyaletinin İdari Taksimatı ve Tevcihatı", Trabzon Tarihi Illmi Toplantisl (6-8 Kasım 1998), Trabzon 1999, s.179-192.

KUNT, Metin, "Müteşebbis Bir Osmanlı Veziri: Derviş Mehmed Paşa", Toplum ve Bilim, Sayı: 2, İstanbul 1977, s.43-64.

Bir Osmanlı Valisinin Ylllık Gelir-Gideri Diyarbekir 1670-1671, Boğaziçi Üniversitesi Yayınları, İstanbul 1981.

Sancaktan Eyalete, 1550-1650 Arasında Osmanlı Ümerası ve İl İdaresi, Boğaziçi Üniversitesi Yayınları, İstanbul 1978.

MEHMED SÜREYYA, Sicill-i Osmani, yay. haz. Nuri Akbayar, Tarih Vakfi Yayınları, İstanbul 1996.

MERT, Özcan, “Canikli Ali Paşa Ailesi”, DİA, Cilt 7, İstanbul 1993, s.151-154.

Otur Baştan Yaz Beni: Oto/Biyografiye Taze Bakışlar, yay. haz. Abdulhamit Kırmızı, Küre Yayınları, İstanbul 2013.

ÖZEL, H. Abdulkadir, Koca Ragıb Mehmed Paşa'nın Münşeat ve Telhisatı, DeğerlendirmeMetin, (Mimar Sinan Güzel Sanatlar Üniversitesi Sosyal Bilimler Enstitüsü Yayımlanmamış Yüksek Lisans Tezi), İstanbul 2014.

ÖZGER, Yunus, “Trabzon Valisi Hazinedarzade Süleyman Paşa'nın Muhallefatı”, Karadeniz Incelemeleri Dergisi, Say1 2, Trabzon 2007, s. 93-122.

ÖZTÜRK, Temel, “Arşiv Belgelerine Göre Trabzon'da Üçüncüoğlu Sarayı”, Trabzon Kent Mirast: Yer-Yapt-Hafiza, Klasik Yayınları, İstanbul 2010, s. 237-264.

“Trabzon Valisi Üçüncüoğlu Ömer Pașa'nın (1739-1742) Kitap Kültürü”, Osmanlı Sosyal ve Ekonomik Tarihi: Prof. Dr. Yllmaz Kurt Armağanı, II. cilt, Ankara 2016, s. $212-235$. 
“Trabzon Valisi Vezir Abdurrahman Paşa'nın (1728-1730) Kitap Kültürü”, XVII. Türk Tarih Kongresi, Ankara: 15-17 Eylül 2014: Kongreye Sunulan Bildiriler, IV. Cilt III. Kisim, Ankara 2018, s. 1093-1110.

“Trabzon Valisi Vezir Abdurrahman Paşa'nın Muhallefatı (1728-1730)”, Türk Kültürü Incelemeleri Dergisi, Say1 18, İstanbul 2008, s. 9-50.

ÖZVAR, Erol, "Voyvoda”, DIA, Cilt 43, İstanbul 2019, s.129-131.

SALZMANN, Ariel, "İmparatorluğu Özelleştirmek: Osmanlı XVIII. Yüzyılında Paşalar ve Ayanlar", Osmanll-İktisat, Cilt 3, Ankara 1999, s.227-235.

Osmanlı Ancien Regimei, İletişim Yayınları, İstanbul 2011.

Subhi Tarihi: Sami ve Şakir Tarihleri ile Birlikte 1730-1744 (inceleme ve karşılaştırma metin), Haz. Mesut Aydıner, Kitabevi Yayınları, İstanbul 2007.

ŞAHIN, Canay, The Rise and Fall of an Ayan Family in $18^{\text {th }}$ Century Anatolia: The Caniklizade's(1737-1808), (Bilkent Üniversitesi Ekonomi ve Sosyal Bilimler Enstitüsü Yayımlanmamış Doktora Tezi), Ankara 2003.

Şemdanizade Findıklılı Süleyman Efendi Tarihi-Müri't-Tevarih, haz. M. Münir Aktepe, 3 Cilt, İstanbul 1976-1981.

TOSUN, Miraç, Şeriye Sicillerine Göre Trabzon'da Mülk Satışları 1148-1735/1153-1741, (KTÜ Sosyal Bilimler Enstitüsü Yayımlanmamış Yüksek Lisans Tezi), Trabzon 2005.

"XVIII. Yüzyı1 Ortasında Bir Trabzon Valisi: Hekimoğlu Ali Paşa", $23^{\text {rd }}$ Symposium of The Comitee International des Etudes Pre-Ottomanes et Ottomanes(CIEPO), Sofia, 11-15 September 2018, Basılmamış Bildiri.

ULUÇAY, Çağatay, 18. ve 19. Yüzyıllarda Saruhan'da Eşkıyalık ve Halk Hareketleri, Berksoy Basımevi, İstanbul 1955.

ÜLKER, Necmi, “Sarıbeyoğlu'nun İzmir'e Yürüyüşü ve Avrupalı Tüccarlar”, Tarih Incelemeleri Dergisi, Cilt: 4 Sayı:1, İzmir 1989, s. 43-51.

Sarıbeyoğlu Mustafa ve Faaliyetleri 1735-1739, (İstanbul Üniversitesi Edebiyat Fakültesi Tarih Bölümü Yayımlanmamış Mezuniyet Tezi), İstanbul 1964.

YANBEĞ, M. Kemal, “17. ve 18. Asırda Azak Kalesi ve Trabzon Valileri” İnan, Say1 5, Trabzon 1943, s.7-13.

YILMAZÇELIK, İbrahim, "Osmanlı Hâkimiyeti Süresince Diyarbakır Eyaleti Valileri (15161838)", Firat Üniversitesi Sosyal Bilimler Dergisi, Cilt 10, Elazı̆g, 2000, s.233-287. 
EK 1: Ömer Paşa'ya Ait Bir Buyruldu Kaydı(T.Ş.S., nr. 1906, vr. 109b)

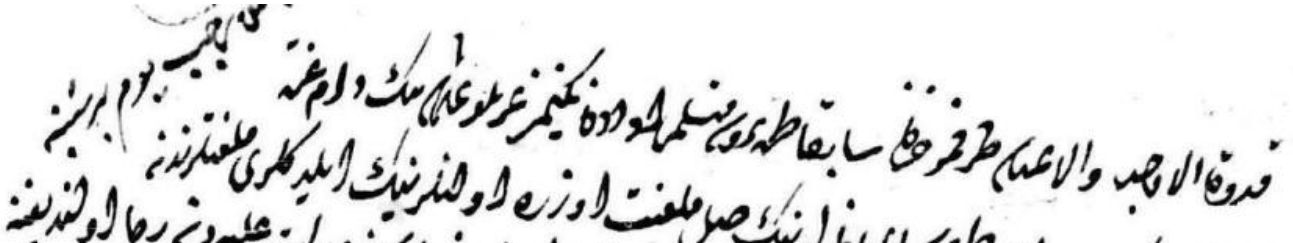
•

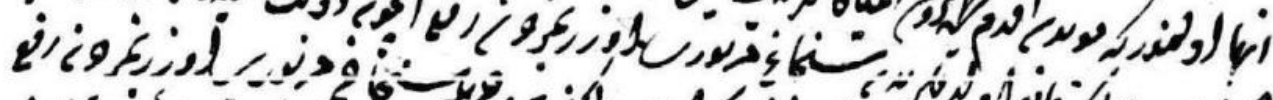

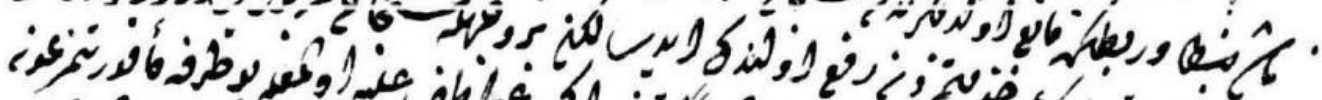

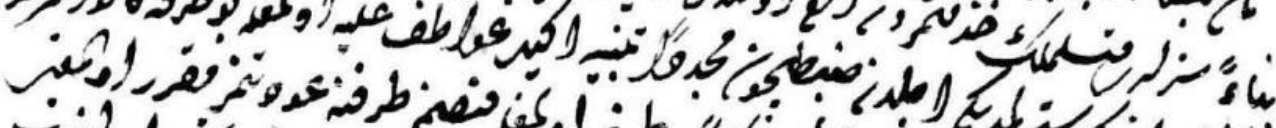

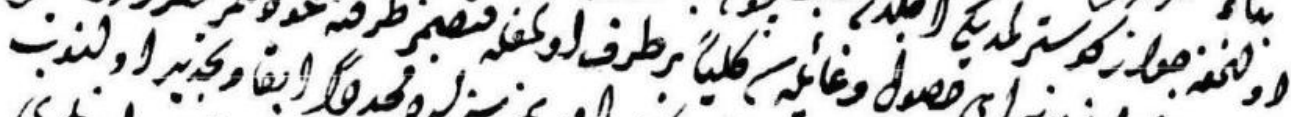

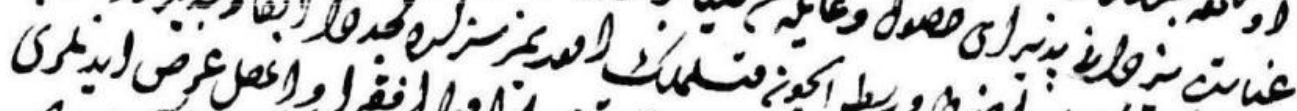

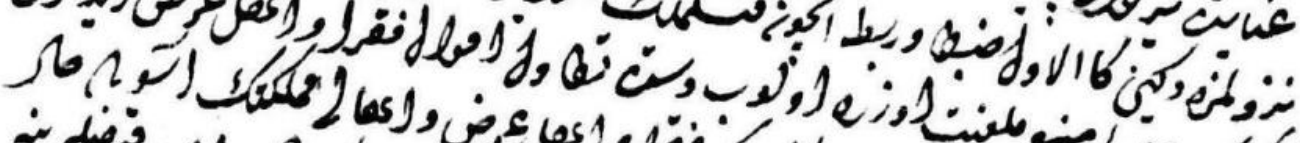

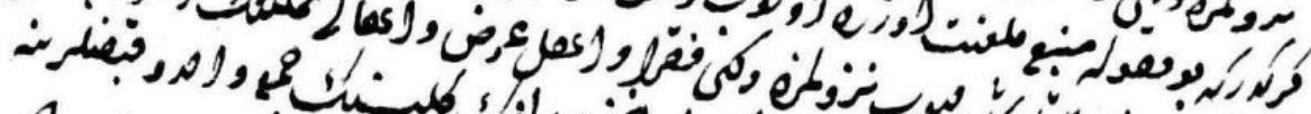

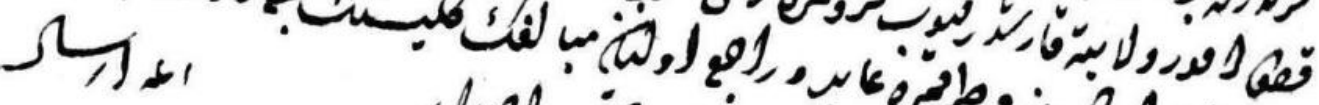

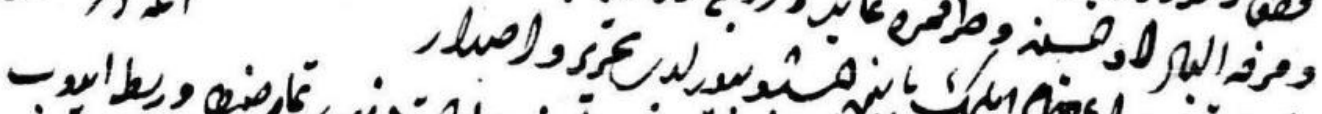

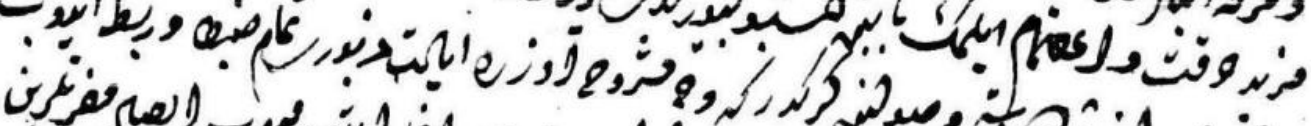

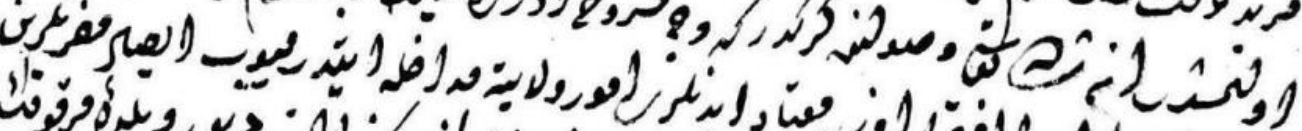

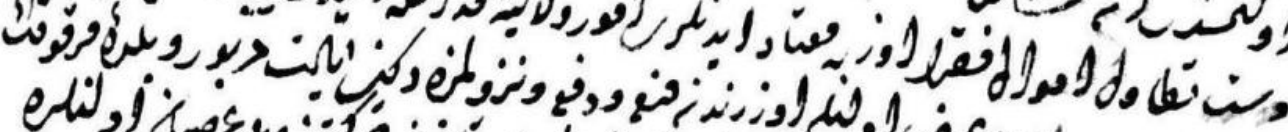

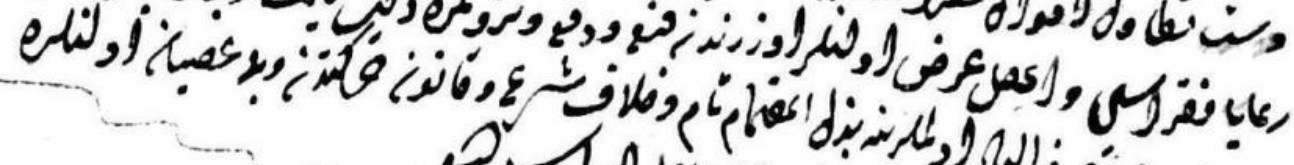

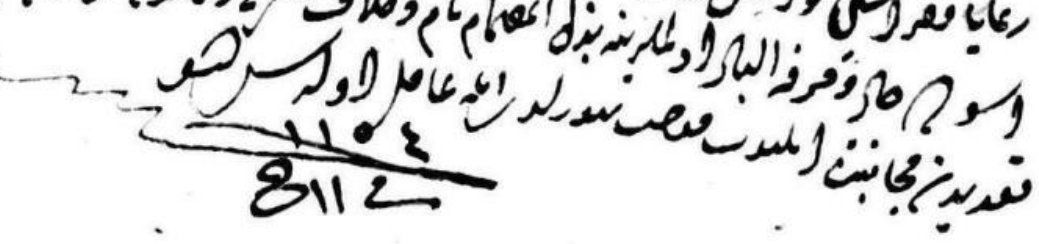

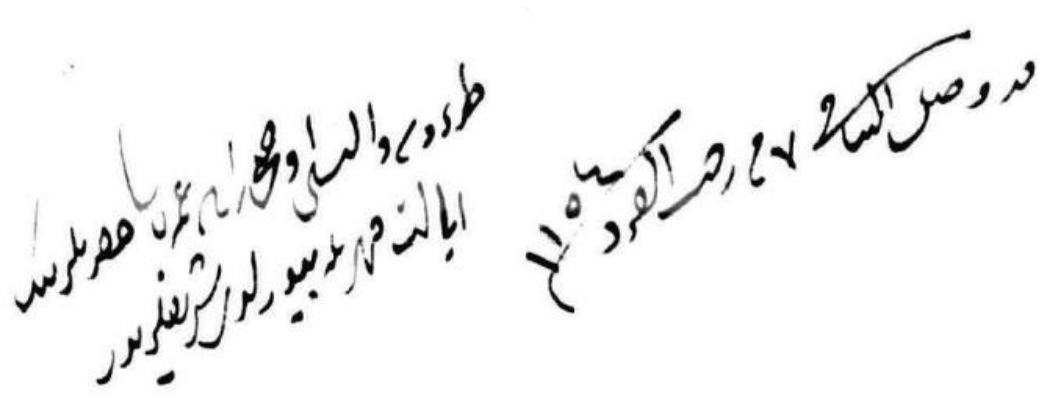


Ek 2: Ömer Paşa’nın Hatuniye Evkafı Tevliyetine ve Cibayetine Ait Berat Kayıtları(T:Ş.S., nr. 1906, vr. 75b)
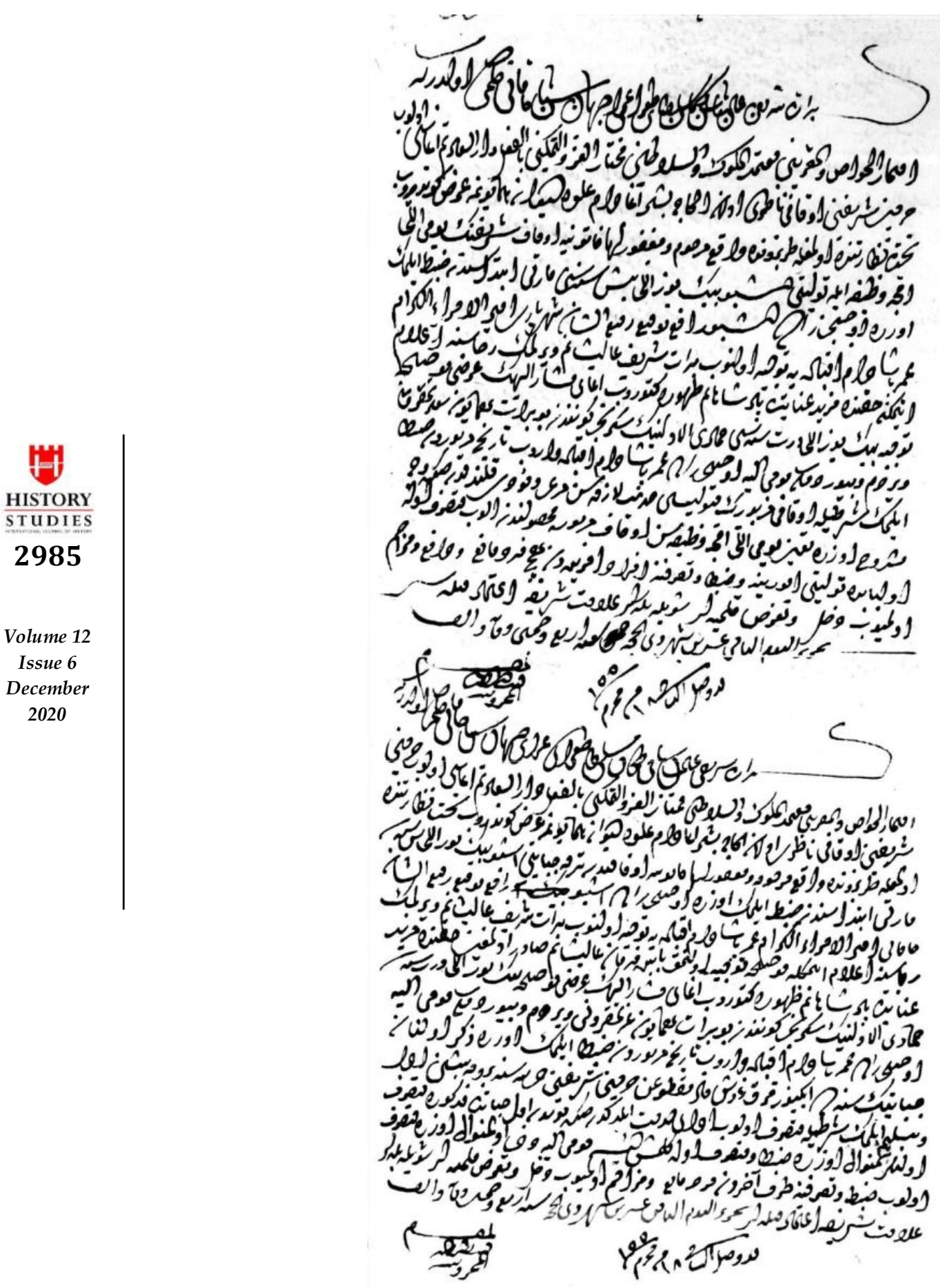


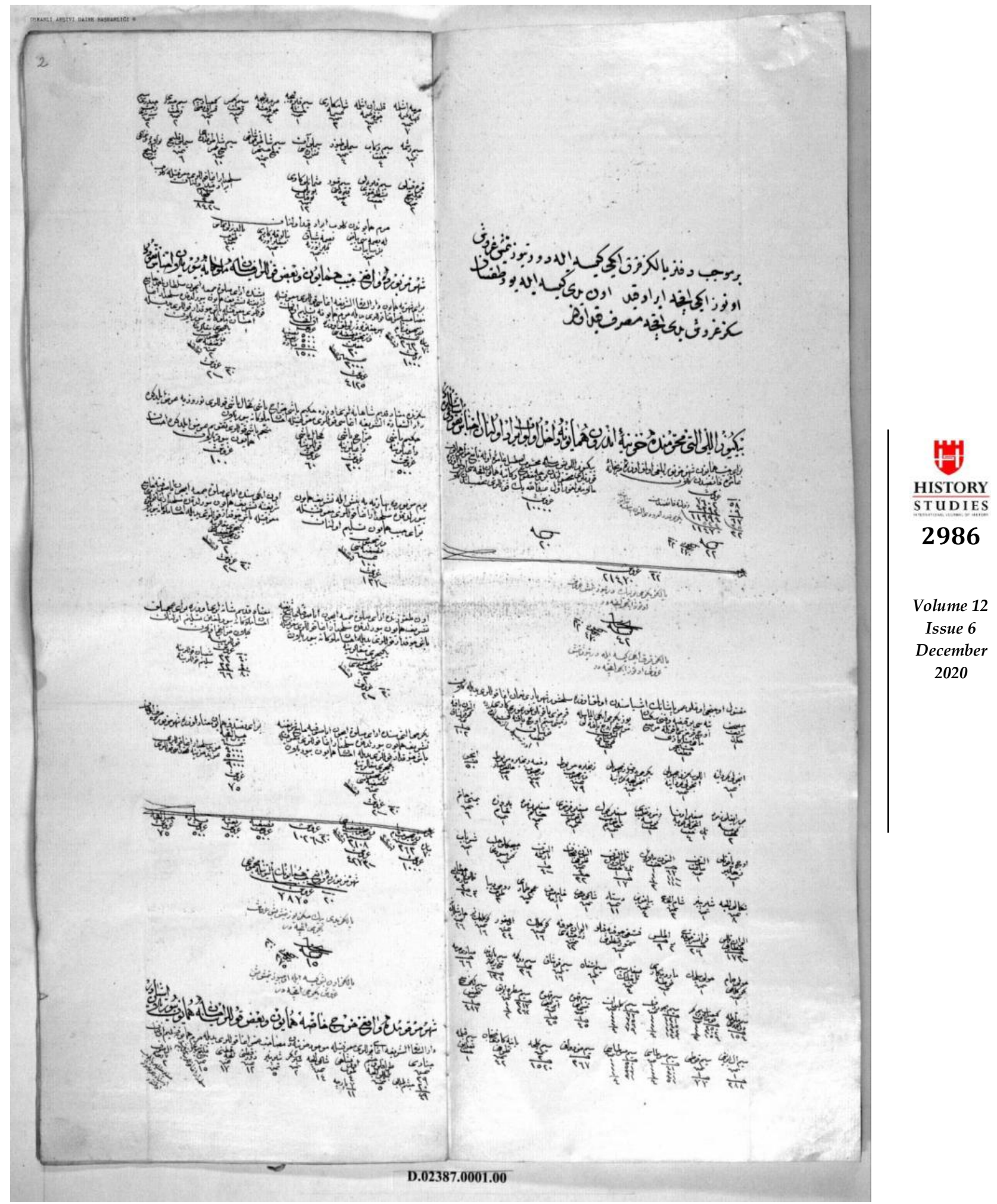

